\title{
Diurnal and Seasonal Variations of Surface Ozone and Its Precursors in the Atmosphere of Yanbu, Saudi Arabia
}

\author{
Hesham A. Al-Jeelani \\ Department of Environmental Sciences, Faculty of Meteorology, Environment \& Arid land Agriculture, King \\ Abdulaziz University \\ Email: yassin64@gmail.com
}

Received 25 December 2013; revised 21 January 2014; accepted 18 February 2014

Copyright (C 2014 by author and Scientific Research Publishing Inc.

This work is licensed under the Creative Commons Attribution International License (CC BY). http://creativecommons.org/licenses/by/4.0/

\section{Open Access}

\section{Abstract}

Surface ozone $\left(\mathrm{O}_{3}\right)$ and its precursor's gases (nitrogen monoxide (NO), nitrogen dioxide $\left(\mathrm{NO}_{2}\right)$, nitrogen oxides $\left(\mathrm{NO}_{\mathrm{x}}\right)$, carbon monoxide ( $\left.\mathrm{CO}\right)$, methane $\left(\mathrm{CH}_{4}\right)$ and non-methane hydrocarbons (NMHCs), and sulfur dioxide $\left(\mathrm{SO}_{2}\right)$ were measured in Yanbu, Saudi Arabia from January 2004-December 2004. The annual average concentrations of $\mathrm{O}_{3}, \mathrm{NO}, \mathrm{NO}_{2}, \mathrm{NOx}, \mathrm{SO}_{2}, \mathrm{CO}_{2} \mathrm{CH}_{4}, \mathrm{TNMHCs}$ and THC were $22.51 \mathrm{ppb}, 15.58 \mathrm{ppb}, 17.25 \mathrm{ppb}, 23.84 \mathrm{ppb}, 6.66 \mathrm{ppb}, 165.13 \mathrm{ppb}, 3.44 \mathrm{ppm}, 0.56 \mathrm{ppm}$ and $3.88 \mathrm{ppm}$, respectively. The $\mathrm{SO}_{2} / \mathrm{NO}_{\mathrm{x}}$ and $\mathrm{SO}_{2} / \mathrm{NO}_{2}$ concentration ratios during the period of study indicate that the mobile emissions are the predominant sources in yanbu. The diurnal cycles $\mathrm{Of}_{3}$ concentrations revealed highest levels in the daytime and lowest levels in night time. The diurnal variations of $\mathrm{NO}, \mathrm{NO}_{2}, \mathrm{NO}_{x}, \mathrm{SO}_{2}, \mathrm{CO}, \mathrm{NMHCs}$ concentrations were similar and showed peaks concentrations linked to traffic density, boundary layer mixing processes and chemical processes in the atmosphere. The mean concentrations of $\mathrm{O}_{3}$ in different seasons follow the order of summer > spring > autumn > winter. In contrary to $\mathrm{O}_{3}$, NO has higher concentrations in autumn and winter than those in summer and spring seasons. The highest concentrations of $\mathrm{NO}_{2}, \mathrm{NO}_{\mathbf{x}}, \mathrm{SO}_{2}, \mathrm{CO}$, and TNMHCs were found in autumn and spring, whereas the lowest concentrations were found in summer and winter. THC and $\mathrm{CH}_{4}$ have no significant change over winter, autumn and summer seasons, while their concentrations decrease sharply in spring. Although the studied area does not suffer from $\mathrm{NO}_{2}, \mathrm{O}_{3}, \mathrm{SO}_{2}$ and $\mathrm{CO}$ pollution and no health risk, comprehensive and long-term air quality management programmes are needed in order to keep air quality in a good condition.

\section{Keywords}

Ozone, Precursors, Diurnal and Seasonal, Urban, Saudi Arabia 


\section{Introduction}

Anthropogenic air pollutants caused by technological progress, industrialization, and urban overpopulation had led to the deterioration of environmental air quality [1]. Toxic air pollutants emitted in close proximity of population areas have the potential to subject such population to health risks [2]. Tropospheric ozone $\left(\mathrm{O}_{3}\right)$ is an important air pollutant threatening human health and vegetation growth [3] [4]. People living in cities with high $\mathrm{O}_{3}$ levels had an over $30 \%$ increased risk of dying from lung disease [5]. $\mathrm{O}_{3}$ is also one of the key species affecting the chemical properties of the atmosphere where it is a precursor for the highly reactive hydroxyl radical [6] [7]. Surface $\mathrm{O}_{3}$ and its precursors play an important role in affecting regional climates and causing adverse effects on human health and vegetation [8].

There are two sources of tropospheric $\mathrm{O}_{3}$, viz. photochemical production [9] and downward transport of ozone from the stratosphere [10]. Ground level $\mathrm{O}_{3}$ is a major constituent of smog in urban areas where motor vehicles are the main anthropogenic emission source of its precursors [11]. It is produced mainly by photochemistry involving pollutants that are released from various industrial and other anthropogenic activities, e.g., $\mathrm{CH}_{4}$, $\mathrm{CO}$ and [12]. $\mathrm{NO}_{\mathrm{x}}$ and hydrogen oxide radicals act as catalysts in this process. The relation between $\mathrm{O}_{3}$ and its main precursors represents one of the major scientific challenges associated with urban air pollution [13].

Ozone concentrations depend on the absolute and relative concentrations of its precursors and the intensity of solar radiation [14]. Variations in $\mathrm{O}_{3}$ concentration are controlled by a number of processes including photochemistry, physical/chemical removal, and transport, which occur on local, regional and global scales [15]. The variations in local meteorological conditions, such as wind direction, wind speed, temperature, and relative humidity, can affect the temporal variations in $\mathrm{O}_{3}$ and its precursors [16]. An analysis of the influences of meteorological parameters on $\mathrm{O}_{3}$ and its precursors at a specific site can contribute to a better understanding of the local and regional causes of $\mathrm{O}_{3}$ pollution [8]. The seasonal and diurnal variations of surface $\mathrm{O}_{3}$ and its precursors and the related meteorology have been extensively studied around the world [17] [18]. These studies showed that $\mathrm{O}_{3}$ chemistry and the effects of meteorological conditions could vary depending on the characteristics of the climate and air pollutants emissions in the place of interest. The temporal variations of $\mathrm{O}_{3}$ have been reported at many sites including rural, urban, coast and mountain sites in India [19], Japan [20], Thailand [21] and Kuwait [14].

Large quantities of non-methane hydrocarbons (NMHC) are emitted in the troposphere from vegetation and from a variety of anthropogenic sources. These anthropogenic sources include incomplete combustion sources (vehicle and fossil fueled power plant emissions), fuel storage and transport, solvent usage, emissions from industrial operations, landfills, and hazardous waste facilities [22] [23]. $\mathrm{NO}_{\mathrm{x}}$ are also emitted, or produced in the troposphere. Nitrogen monoxide (NO) is emitted from soils and natural fires and formed in situ in the troposphere from lightning, and is emitted from combustion processes such as vehicle emissions and fossil fueled power plants [22] [23]. NO is short lived because it oxidizes to produce nitrogen dioxide gas $\left(\mathrm{NO}_{2}\right)$ and plays a major role in $\mathrm{O}_{3}$ production. In urban areas, $\mathrm{NMHC}$ and $\mathrm{NO}_{\mathrm{x}}$, from anthropogenic sources dominate over NMHC and $\mathrm{NO}_{\mathrm{x}}$ from biogenic sources, and the reverse is generally the case in rural and remote areas [24].

Biomass burning [25], combustion of fossil fuels, and oxidation of hydrocarbons released from automobiles and industrial solvents are the main sources of atmospheric CO [26]. Its oxidation leads to O3 formation or destruction, depending upon the NO concentration [27]. The reaction of CO with $\mathrm{OH}$ radicals is the primary removal process from the atmosphere. Through this mechanism, CO acts as a major precursor to photochemical ozone [9].

In order to reduce ambient ozone concentrations, anthropogenic VOC emissions, which predominantly consist of non-methane hydrocarbons $\left(\mathrm{NMHC}_{\mathrm{s}}\right.$ ) have been the subject of extensive control programs in many countries. Accurate characterization of ozone precursors is extremely important for understanding tropospheric ozone formation and crafting effective control strategies to better address ozone air quality management issues [28]. The objective of the present study is to investigate the seasonal and diurnal variations of surface O3 and its precursors ( $\mathrm{NO}, \mathrm{NO}_{2}, \mathrm{NO}_{\mathrm{x}}, \mathrm{CO}, \mathrm{THC}, \mathrm{CH}_{4}$ and TNMHCs), and $\mathrm{SO}_{2}$ in the atmosphere of yanbu Al Sinaiyah, and compare the concentrations of these pollutants with the standard limits.

\section{Materials and Methods}

\subsection{Study Area}

Yanbu Al Sinaiyah is a city in the Hejaz region of western Saudi Arabia. It has a population of more than 66,381 
people. It is located about $350 \mathrm{~km}$ northwest of Jeddah. It is a terminal for oil pipelines and gas, which, stretching from the production areas in eastern Saudi Arabia to the west and it is the largest port on the Red Sea coast for the export of crude oil [29]. There are two types of industries in Yanbu Al Sinaiyah, which are traditional local industries and modern industries. The traditional local industries include building of sailing ships and fishing boats, furniture, traditional agricultural machinery, wicker industry, leather industry, woolens industry and jewelry industry. The modern industries include oil refining, sort of liquid natural gas, petrochemical industry, lubricants and oil additives industry.

Yanbu has a hot desert climate. The climate of Yanbu Al Sinaiyah is characterized by high temperature and dryness. The maximum temperature reaches up more than $40^{\circ} \mathrm{C}$ in the summer, while temperature in the winter is between $28^{\circ} \mathrm{C}$ and $15^{\circ} \mathrm{C}$. The relative humidity is between $25 \%$ (dry) and $83 \%$ (humid). The average annual rainfall is lower than $50 \mathrm{~mm}$. Over the course of the year typical wind speeds vary from $0 \mathrm{mph}$ to $23 \mathrm{mph}$ (calm to fresh breeze), rarely exceeding $30 \mathrm{mph}$ (strong breeze). The wind is most often out of the west (31\% of the time). The wind is least often out of the north (3\% of the time), south east ( $3 \%$ of the time), north east ( $5 \%$ of the time), south (5\% of the time), and east (5\% of the time).

\subsection{Air Sampling}

Air quality monitoring mobile station (Environment SA, France) was used to conduct the measurements of pollutants including: $\mathrm{NO}, \mathrm{NO}_{2}, \mathrm{NO}_{\mathrm{x}}, \mathrm{O}_{3}, \mathrm{CO}, \mathrm{SO}_{2}$, THC, $\mathrm{NMHCs}$ and $\mathrm{CH}_{4}$. Calibration was daily done and no data was recorded during that period. Average hourly measurements were taken in the period of January 2004 to December 2004.

\section{Results and Discussion}

\subsection{Status of $\mathrm{O}_{3}$ and Its Precursors}

The statistical summary of daily average concentrations of $\mathrm{O}_{3}, \mathrm{NO}, \mathrm{NO}_{2}, \mathrm{NO}_{\mathrm{x}}, \mathrm{SO}_{2}, \mathrm{CO}, \mathrm{THC}, \mathrm{CH}_{4}$ and TNMHC during the period of study (January 2004 to December 2004) are shown in Table 1. Seasons are defined as: spring is March, April and May; summer is June, July and August; autumn is September, October and November; winter is December, January and February. The daily average concentration ranged from 5.44 to $50.68 \mathrm{ppb}$ (with a mean value of 22.51ppb) for $\mathrm{O}_{3}, 6.04$ to $45.47 \mathrm{ppb}$ (with a mean value of $15.58 \mathrm{ppb}$ ) for NO, 5.42 to $36.74 \mathrm{ppb}$ (with a mean value of $17.25 \mathrm{ppb}$ ) for $\mathrm{NO}_{2}, 8.83$ to $89.70 \mathrm{ppb}$ (with a mean value of $32.84 \mathrm{ppb}$ ) for $\mathrm{NO}_{\mathrm{x}}, 1.00$ to $53.56 \mathrm{ppb}$ (with a mean value of $6.66 \mathrm{ppb}$ ) for $\mathrm{SO}_{2}, 32.92$ to $1006.67 \mathrm{ppb}$ (with a mean value of $165.13 \mathrm{ppb}$ ) for CO, 0.76 to $6.27 \mathrm{ppm}$ (with a mean value of $3.88 \mathrm{ppm}$ ) for THC, 0.64 to $5.65 \mathrm{ppm}$ (with a mean value of $3.44 \mathrm{ppm}$ ) for $\mathrm{CH}_{4}, 0.10$ to $3.45 \mathrm{ppm}$ (with a mean value of $0.56 \mathrm{ppm}$ ) for TNMHC during the period of study.

The results of daily (24-h) minimum, maximum and average concentrations of $\mathrm{NO}_{2}, \mathrm{O}_{3}, \mathrm{SO}_{2}$ and $\mathrm{CO}$ were compared with the available air quality standards in different countries. The concentrations of these pollutants did not exceed the available standards. Although, the studied area does not suffer from $\mathrm{NO}_{2}, \mathrm{O}_{3}, \mathrm{SO}_{2}$ and $\mathrm{CO}$ pollution and no health risk, comprehensive, long-term air quality management programmers are needed in order to keep air quality in a good condition.

\subsection{Diurnal Variations in $\mathrm{O}_{3}$ and Its Precursors}

The diurnal variations in $\mathrm{O}_{3}, \mathrm{NO}, \mathrm{NO}_{2}, \mathrm{NO}_{\mathrm{x}}, \mathrm{CO}$, and $\mathrm{SO}_{2}$ concentrations during the period of study are represented graphically in Figure 1. From this figure, it can be noticed that the diurnal variation of $\mathrm{O}_{3}$ is characterized by high concentrations during daytime and low concentrations during late night and morning. The minimum $\mathrm{O}_{3}$ concentration appears during the morning hours $\left(7.00\right.$ - 9.00). The maximum $\mathrm{O}_{3}$ concentration appears at around $11.00 \mathrm{~h}$ in summer, at around $12.00 \mathrm{~h}$ in spring, at around $14.00-17.00 \mathrm{~h}$ in autumn and at around $17.00 \mathrm{~h}$ in winter. The increase in $\mathrm{O}_{3}$ concentration during daytime is due to the increase in solar radiation intensity which favors the conditions to power the photochemical reactions [30]. Significant increasing $\mathrm{O}_{3}$ values during daytime were observed at an urban site in tropical India [31]. The decrease in $\mathrm{O}_{3}$ concentration during late night and morning is due to the absence of the photochemical reactions and the consumption of $\mathrm{O}_{3}$ by deposition and or reaction with $\mathrm{NO}$ and $\mathrm{NO}_{2}$ which act as a sink for $\mathrm{O}_{3}$ [30].

The diurnal variations of $\mathrm{O}_{3}$ for the four seasons show a similar pattern; however, the amplitudes of the varia- 
Table 1. Statistical summary of daily averaged concentrations of $\mathrm{O}_{3}, \mathrm{NO}, \mathrm{NO}_{2}, \mathrm{NO}_{\mathrm{x}}, \mathrm{SO}_{2}, \mathrm{CO}, \mathrm{THC}, \mathrm{CH}_{4}$ and $\mathrm{TNMHC}$ in different seasons over the period from January 2004 to November 2004.

\begin{tabular}{|c|c|c|c|c|c|c|}
\hline \multirow{2}{*}{ Pollutants } & \multirow{2}{*}{ Statistics } & \multicolumn{4}{|c|}{ Season } & \multirow{2}{*}{ Annual } \\
\hline & & Winter & Spring & Summer & Autumn & \\
\hline \multirow{5}{*}{$\mathrm{O}_{3}(\mathrm{ppb})$} & Min. & 7.96 & 7.40 & 8.05 & 5.44 & 5.44 \\
\hline & Max. & 30.54 & 50.68 & 41.52 & 46.05 & 50.68 \\
\hline & Median & 16.49 & 26.08 & 24.40 & 19.88 & 20.92 \\
\hline & Mean & 17.20 & 25.79 & 24.91 & 20.94 & 22.51 \\
\hline & S.D. & 4.10 & 9.93 & 8.87 & 8.45 & 8.97 \\
\hline \multirow{5}{*}{$\mathrm{NO}_{\mathrm{x}}(\mathrm{ppb})$} & Min. & 15.00 & 16.28 & 19.56 & 8.83 & 8.83 \\
\hline & Max. & 59.04 & 89.70 & 89.70 & 61.80 & 89.70 \\
\hline & Median & 27.58 & 28.80 & 26.72 & 41.36 & 31.12 \\
\hline & Mean & 29.16 & 30.41 & 29.26 & 42.53 & 32.84 \\
\hline & S.D. & 9.14 & 9.85 & 9.18 & 8.55 & 9.18 \\
\hline \multirow{5}{*}{$\mathrm{NO}_{2}(\mathrm{ppb})$} & Min. & 8.88 & 9.68 & 9.36 & 5.42 & 5.42 \\
\hline & Max. & 23.32 & 36.74 & 25.68 & 31.00 & 36.74 \\
\hline & Median & 15.98 & 16.68 & 14.04 & 21.12 & 16.96 \\
\hline & Mean & 15.98 & 17.00 & 14.85 & 21.17 & 17.25 \\
\hline & S.D. & 3.42 & 3.55 & 3.43 & 3.16 & 3.39 \\
\hline \multirow{5}{*}{ NO (ppb) } & Min. & 6.04 & 6.16 & 6.36 & 6.67 & 6.04 \\
\hline & Max. & 34.48 & 25.28 & 27.68 & 45.47 & 45.47 \\
\hline & Median & 14.60 & 12.44 & 11.54 & 18.68 & 14.32 \\
\hline & Mean & 16.03 & 13.58 & 12.32 & 20.38 & 15.58 \\
\hline & S.D. & 7.10 & 5.31 & 3.94 & 6.92 & 5.82 \\
\hline \multirow{5}{*}{$\mathrm{SO}_{2}(\mathrm{ppb})$} & Min. & 2.44 & 1.00 & 1.23 & 5.20 & 1.00 \\
\hline & Max. & 13.08 & 22.60 & 53.56 & 25.88 & 53.56 \\
\hline & Median & 3.54 & 4.72 & 3.06 & 8.72 & 5.01 \\
\hline & Mean & 4.39 & 6.48 & 5.51 & 10.24 & 6.66 \\
\hline & S.D. & 2.17 & 4.53 & 7.14 & 4.50 & 4.59 \\
\hline \multirow{5}{*}{ CO (ppb) } & Min. & 76.00 & 32.92 & 32.92 & 66.67 & 32.92 \\
\hline & Max. & 336.80 & 377.60 & 266.80 & 1006.67 & 1006.67 \\
\hline & Median & 153.20 & 153.60 & 123.40 & 162.40 & 148.15 \\
\hline & Mean & 161.42 & 170.86 & 134.00 & 194.25 & 165.13 \\
\hline & S.D. & 57.70 & 69.27 & 52.13 & 132.02 & 77.78 \\
\hline \multirow{5}{*}{ THC (ppm) } & Min. & 3.59 & 1.39 & 1.39 & 0.76 & 0.76 \\
\hline & Max. & 5.45 & 4.81 & 6.27 & 5.58 & 6.27 \\
\hline & Median & 4.51 & 2.59 & 4.18 & 4.31 & 3.90 \\
\hline & Mean & 4.55 & 2.90 & 4.01 & 4.05 & 3.88 \\
\hline & S.D. & 0.43 & 0.78 & 1.27 & 0.96 & 0.86 \\
\hline \multirow{5}{*}{$\mathrm{CH}_{4}(\mathrm{ppm})$} & Min. & 3.19 & 1.24 & 1.34 & 0.64 & 0.64 \\
\hline & Max. & 4.99 & 4.70 & 5.65 & 4.85 & 5.65 \\
\hline & Median & 4.15 & 2.57 & 3.55 & 3.65 & 3.48 \\
\hline & Mean & 4.15 & 2.58 & 3.61 & 3.42 & 3.44 \\
\hline & S.D. & 0.46 & 0.77 & 1.25 & 0.84 & 0.83 \\
\hline \multirow{5}{*}{ TNMHC (ppm) } & Min. & 0.31 & 0.10 & 0.22 & 0.42 & 0.10 \\
\hline & Max. & 0.55 & 3.45 & 1.11 & 0.90 & 3.45 \\
\hline & Median & 0.42 & 0.56 & 0.41 & 0.67 & 0.52 \\
\hline & Mean & 0.42 & 0.70 & 0.43 & 0.67 & 0.56 \\
\hline & S.D. & 0.05 & 0.65 & 0.14 & 0.09 & 0.23 \\
\hline
\end{tabular}




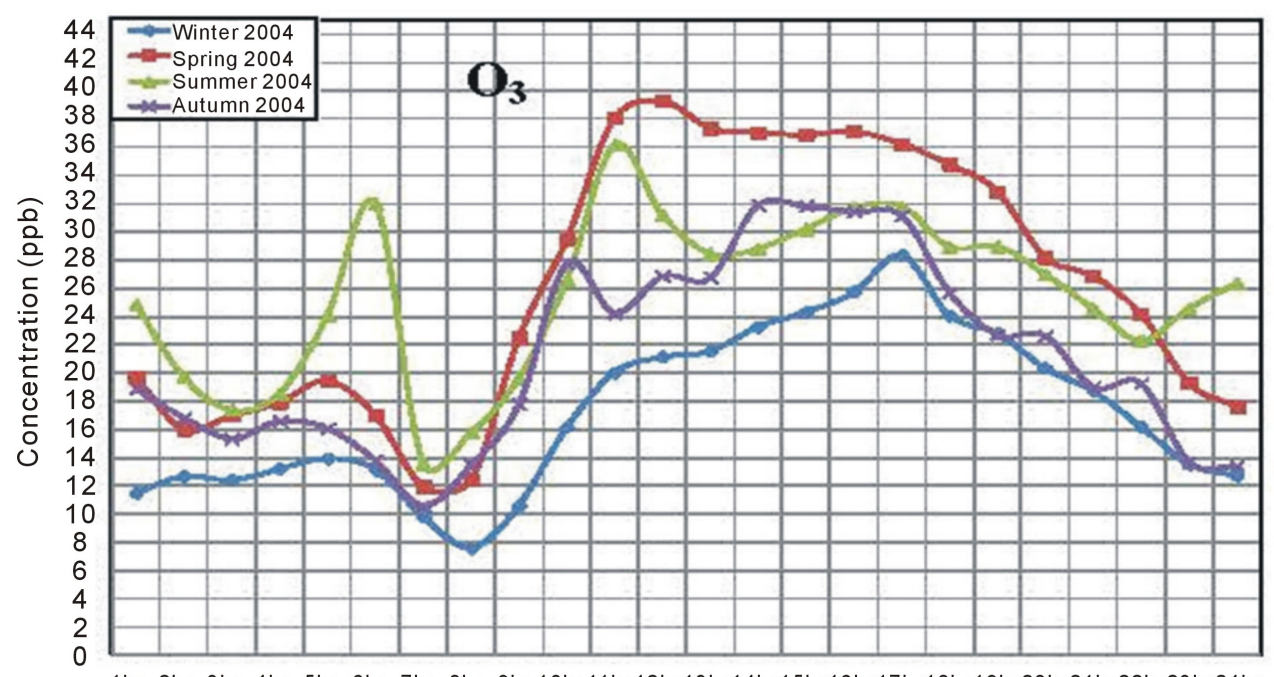

$1 \mathrm{hr} 2 \mathrm{hr} 3 \mathrm{hr} 4 \mathrm{hr} 5 \mathrm{hr} 6 \mathrm{hr} 7 \mathrm{hr} 8 \mathrm{hr} 9 \mathrm{hr} 10 \mathrm{hr} 11 \mathrm{hr} 12 \mathrm{hr} 13 \mathrm{hr} 14 \mathrm{hr} 15 \mathrm{hr} 16 \mathrm{hr} 17 \mathrm{hr} 18 \mathrm{hr} 19 \mathrm{hr} 20 \mathrm{hr} 21 \mathrm{hr} 22 \mathrm{hr} 23 \mathrm{hr} 24 \mathrm{hr}$

Hours

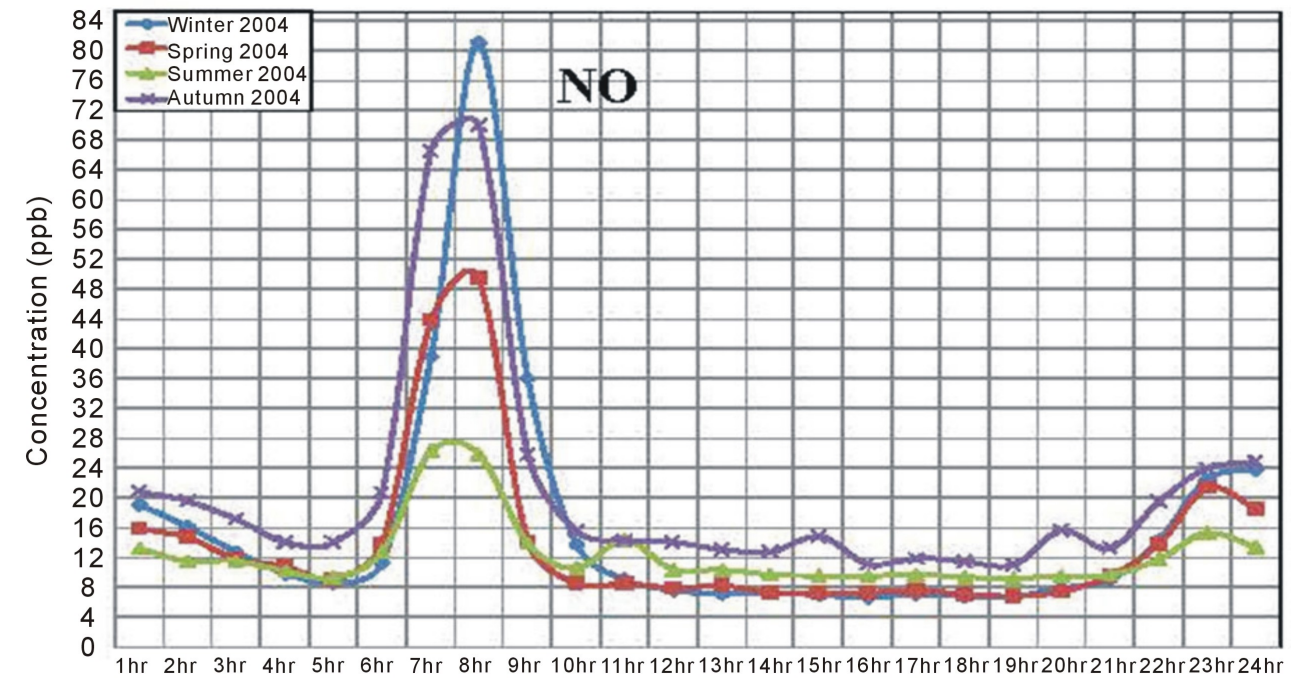

Hours

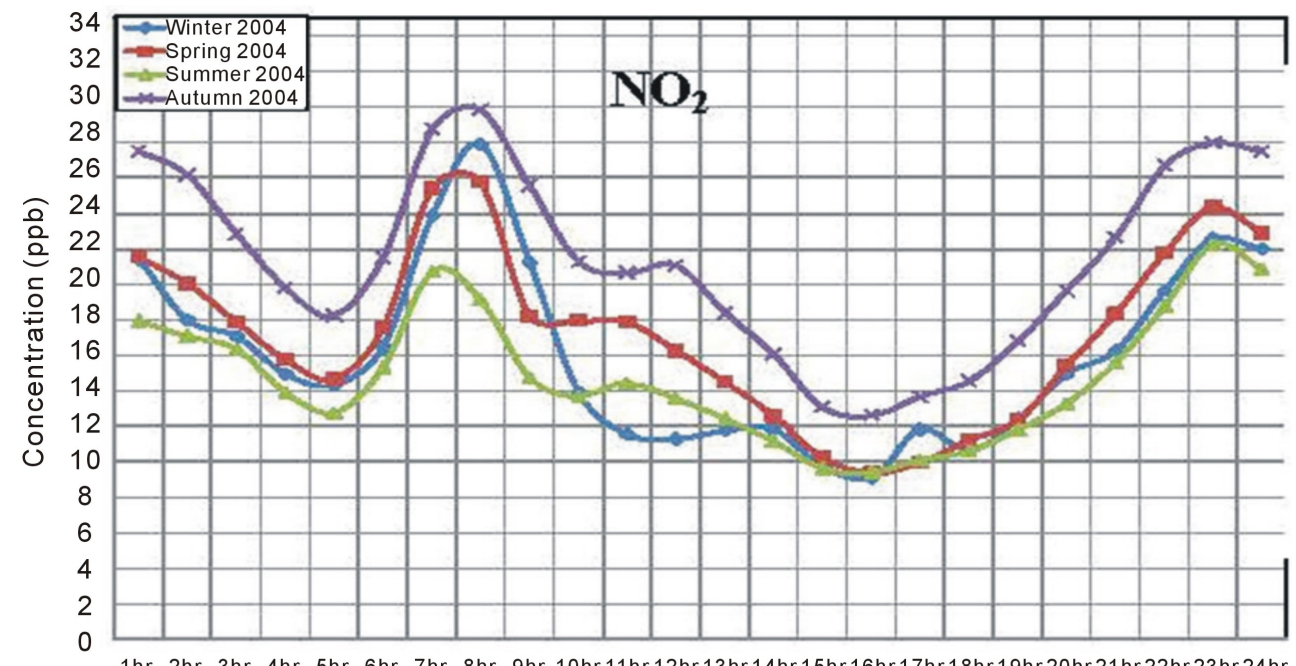

$1 \mathrm{hr} 2 \mathrm{hr} 3 \mathrm{hr} 4 \mathrm{hr} 5 \mathrm{hr} 6 \mathrm{hr} 7 \mathrm{hr} 8 \mathrm{hr} 9 \mathrm{hr} 10 \mathrm{hr} 11 \mathrm{hr} 12 \mathrm{hr} 13 \mathrm{hr} 14 \mathrm{hr} 15 \mathrm{hr} 16 \mathrm{hr} 17 \mathrm{hr} 18 \mathrm{hr} 19 \mathrm{hr} 20 \mathrm{hr} 21 \mathrm{hr} 22 \mathrm{hr} 23 \mathrm{hr} 24 \mathrm{hr}$

Hours 

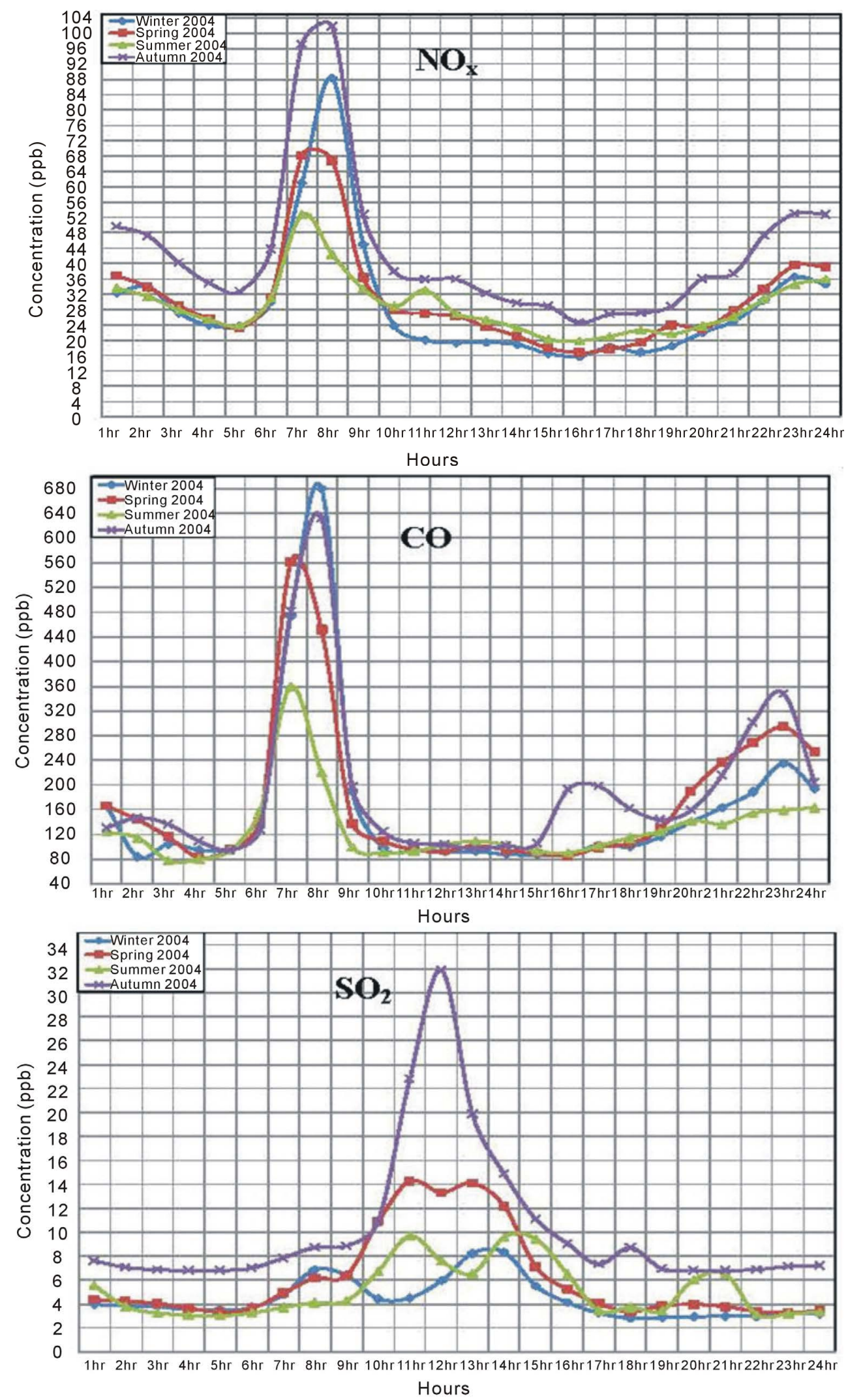

Figure 1. Diurnal variation in $\mathrm{O}_{3}, \mathrm{NO}, \mathrm{NO}_{2}, \mathrm{NO}_{\mathrm{x}}, \mathrm{CO}$ and $\mathrm{SO}_{2}$ concentration in Yanbu during the different seasons. 
tions and position of peaks are different. The maximum amplitude is the highest in summer and spring, the second highest in autumn, and the lowest in winter. This may be attributed to the higher photochemical reactions during the summer seasons. The seasonal variation of $\mathrm{O}_{3}$ at an urban area, Nagoya, Japan, showed that higher concentrations were observed from late spring to summer, while lower concentrations were observed in winter [32]. Elevated levels of $\mathrm{O}_{3}$, frequently encountered in the large urban centers to exhibit variable concentration profiles [33] with maximum levels occurring during the summer months [34] are becoming a cause of global concern.

The ozone precursors, $\mathrm{NO}, \mathrm{NO}_{2}, \mathrm{NO}_{\mathrm{x}}$ and $\mathrm{CO}$, show an almost opposite diurnal variation pattern to $\mathrm{O}_{3}$ (Figure 1), characterized by high concentrations during night and morning and low concentrations during daytime, especially noon and afternoon. Each pollutant has two main peak concentration levels; the first peak appears in the morning rush hours (6:00 - 9:00); the second one appears around late night (22:00 - 2:00), but for CO the second one appears around (22:00 - 24:00). The morning rush hour peak is mainly caused by traffic. These precursors reach their minimum values at around 4:00 - 6:00 and at around 15:00 - 17:00 when $\mathrm{O}_{3}$ reaches its high values. The double peak patterns of $\mathrm{NO}, \mathrm{NO}_{2}, \mathrm{NO}_{\mathrm{x}}$ and $\mathrm{CO}$ may be atypical signature of urban influence boundary layer processes, surface wind pattern, emissions, transportation/work cycle and chemical processes. During the morning time, the increase in the emission rate from traffic, accompanied with a poorer dispersive conditions and lower photochemical reaction lead to accumulate the concentrations of air pollutants. Latha and Badarinath [35] reported that high levels of $\mathrm{NO}_{\mathrm{x}}$ during morning and late evening can be attributed to combinations of anthropogenic emissions, boundary layer processes, chemistry as well as local sources and wind patterns. In the present study, the low concentrations of $\mathrm{NO}$ and $\mathrm{NO}_{2}$ during the mid-day time may be due to the high dispersion and high dilution conditions under the effect of high temperature, which increases the thermal turbulence currents. Moreover, the high temperature and solar radiation intensity during the mid-day time lead to increasing the photochemical reactions and consequently increasing the chemical loss of those pollutants. This leads todecreasing the $\mathrm{NO}_{\mathrm{x}}$ concentrations in the mid-day time. On the other hand, during the late evening and nighttime, the boundary layer descends and remains low until early morning, thereby resisting the mixing of anthropogenic emissions with the upper layer. Hence, pollutants get trapped in a shallow surface layer resulting in raising levels of $\mathrm{NO}, \mathrm{NO}_{2}$ and $\mathrm{NO}_{\mathrm{x}}$ in the present of study. This is in agreement with Rao et al. [36] [37] who attributed that the variations in $\mathrm{NO}_{\mathrm{x}}$ to variations in boundary layer mixing processes, chemistry, anthropogenic emissions, and local surface wind patterns.

The diurnal variation of $\mathrm{SO}_{2}$ in the present study is characterized by low concentration in early morning, evening and night and high concentration in the other time of the day (Figure 1). The $\mathrm{SO}_{2}$ trend is characterized by two maxima for all seasons except for summer where it has three maxima. The maximum $\mathrm{SO}_{2}$ concentration appears at 12.00 in autumn, at 11.00, 14.00 and 15.00 in summer, at 11.00 and 13.00 in spring and at 13.00 and 14.00 in winter. The high concentration of $\mathrm{SO}_{2}$ in morning, noon and afternoon may be attributed to the primary emissions from factories in this industrial area.

The diurnal variations of THC, $\mathrm{CH}_{4}$ and TNMHC during the period of study are represented graphically in Figure 2. From this figure, it can be noticed that the diurnal variation of THC, $\mathrm{CH}_{4}$ and TNMHC is fluctuated along the day. THC concentration is fluctuated in the range 3.32 - 5.73 ppm in winter, 1.68 - 4.31 ppm in spring, 2.57 - 6.65 ppm in summer and 2.89 - 4.81 ppm in autumn. $\mathrm{CH}_{4}$ concentration is fluctuated in the range 2.91 $5.36 \mathrm{ppm}$ in winter, 1.47 - $3.80 \mathrm{ppm}$ in spring, 2.35 - $5.77 \mathrm{ppm}$ in summer and 2.48 - $4.34 \mathrm{ppm}$ in autumn. TNMHC concentration is fluctuated in the range $0.35-0.50 \mathrm{ppm}$ in winter, $0.57-0.87 \mathrm{ppm}$ in spring, 0.31 $0.55 \mathrm{ppm}$ in summer and $0.56-0.80 \mathrm{ppm}$ in autumn. The trend of $\mathrm{THC}$ and $\mathrm{CH}_{4}$ are the same where autumn has trend opposite to that of the other seasons of the year. This may be due to the presence of additional emission sources of THC and $\mathrm{CH}_{4}$ in the study area. The trend of TNMHC is the same for all seasons of the year.

\subsection{Seasonal Variations in $\mathrm{O}_{3}$ and Its Precursors}

The monthly and seasonal variations of $\mathrm{O} 3, \mathrm{NO}, \mathrm{NO}_{2}, \mathrm{NO}_{\mathrm{x}}, \mathrm{CO}$, and $\mathrm{SO}_{2}$ during the period of study are represented graphically in Figure 3 and Figure 4. From these figures, it can be seen that, $\mathrm{O}_{3}$ shows a well-defined seasonal variation. The low values appear in late autumn and winter (colder periods), while the high values appear in late spring, summer and early autumn (warmer periods). Studies conducted around the world reported high $\mathrm{O}_{3}$ levels during the warmer periods [11] [14]. This common behavior of $\mathrm{O}_{3}$ was justified by the dominant photochemical production process of $\mathrm{O}_{3}$ due to the presence of its precursors and intense solar 


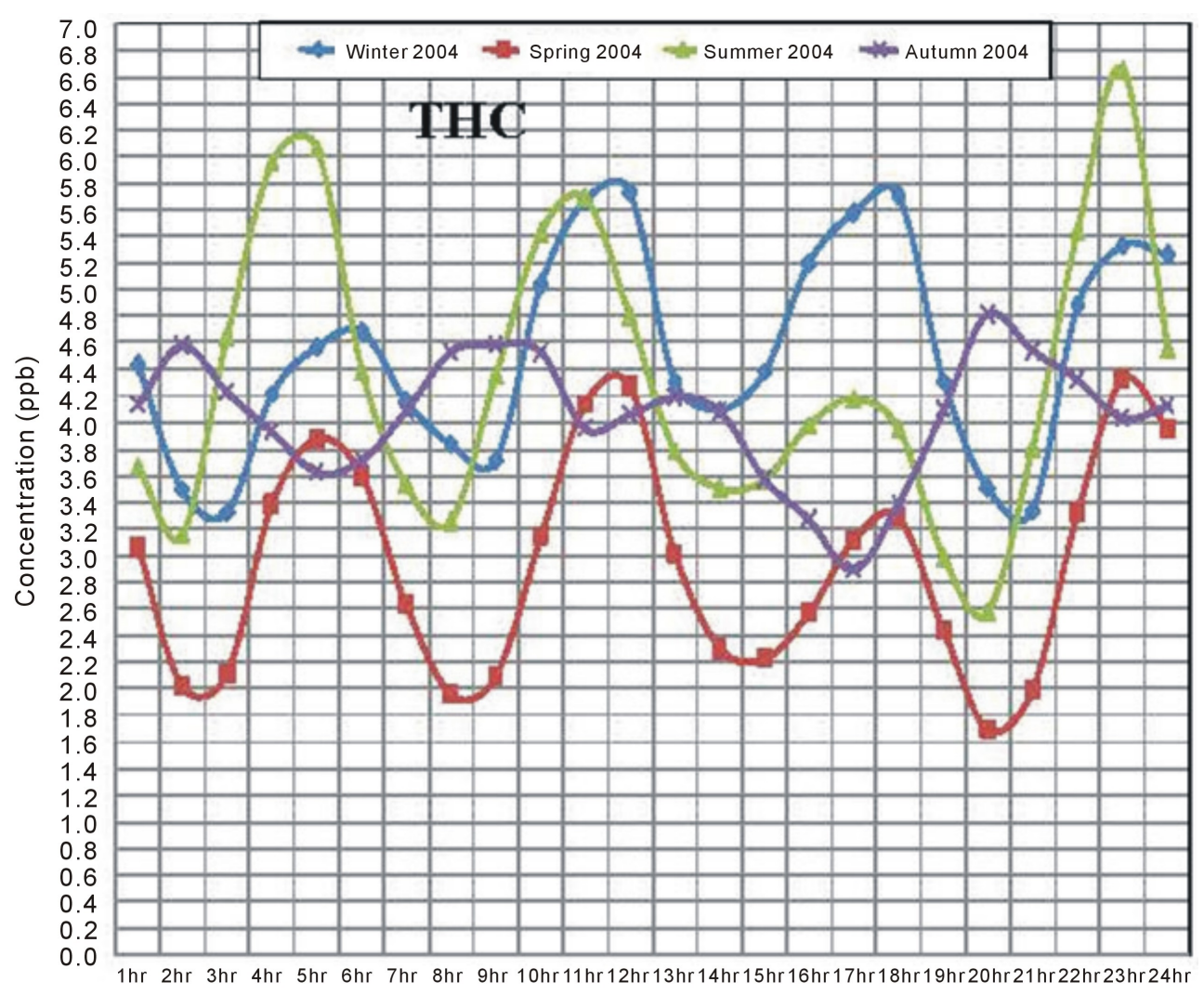

Hours

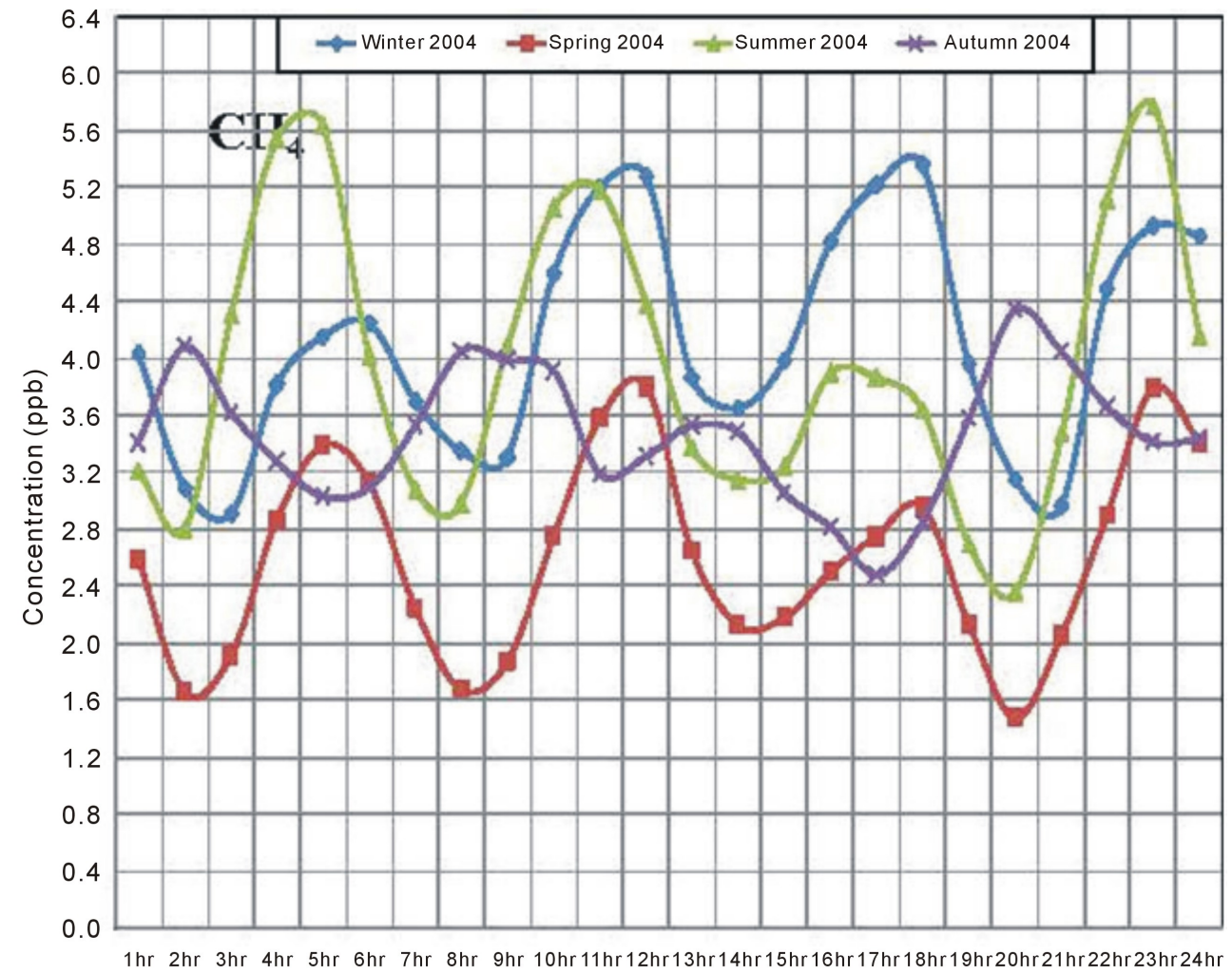

Hours 


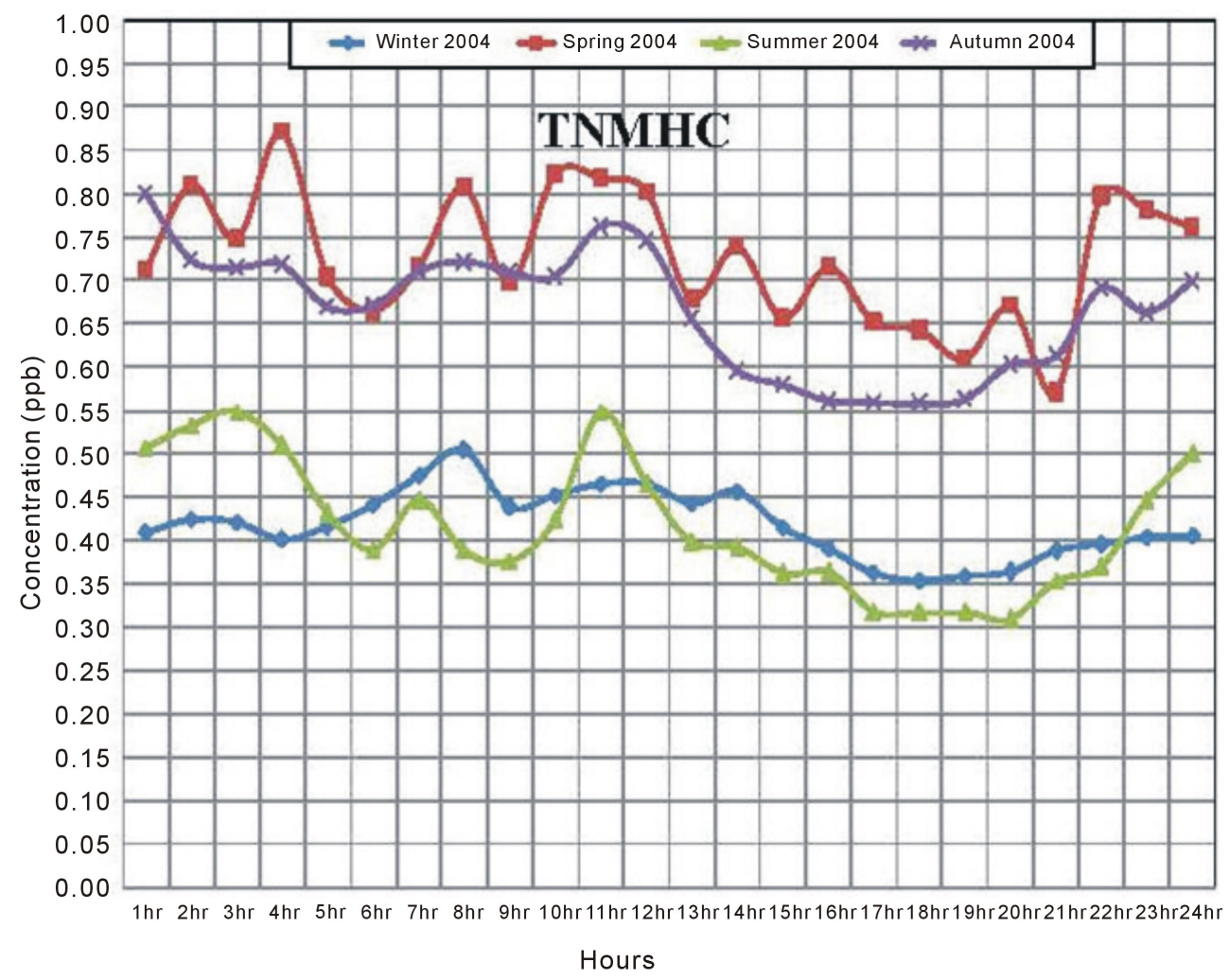

Figure 2. Diurnal variation in THC, $\mathrm{CH}_{4}$, and TNMHC concentration in Yanbu during the different seasons.

insolation during the warmer periods. The low levels of $\mathrm{O}_{3}$ during late autumn and winter (colder periods) is almost the same as that observed in Kuwait [11] and in urban site in China [8].

The $\mathrm{O}_{3}$ precursors, $\mathrm{NO}, \mathrm{NO}_{2}, \mathrm{NO}_{\mathrm{x}}$ and $\mathrm{CO}$, show similar seasonal variations (Figure 3 and Figure 4). The higher values appear in late autumn and winter, while the lower values appear in summer. The seasonal variation pattern of these precursors is almost opposite to that of ozone. This pattern is similar to the results of previous studies performed in many areas around the world [11] [32] [38]. One of the causes of this pattern might partly be attributed to the variation in temperature. For example, the greater photochemical reaction due to the higher solar radiation, and the stronger vertical atmospheric mixing in summer than in the other seasons, contribute to the low values of these pollutants in summer. Another cause is the increase in air pollutant emission in winter due to heating fuels consumed. The monthly and seasonal variation of $\mathrm{SO}_{2}$ in the present study (Figure 3 and Figure 4) is characterized by high concentration in autumn and early winter and the minimum concentration in winter and summer.

Figure 5 shows the seasonal variations of THC, $\mathrm{CH}_{4}$, and TNMHC during the four seasons of year 2004. The seasonal variation of THC and $\mathrm{CH}_{4}$ is the same, where the maximum was in summer (July) and the minimum was in spring (April). The highest concentrations of TNMHC were found in autumn and early winter, whereas the lowest levels were detected in summer (July). The photochemical removal (primarily by the hydroxyl (OH) radical) and dilution due to atmospheric mixing are two important factors that affect the seasonal variation of TNMHCs [39]. The mixing layer in summer is much higher than that in winter. The dilution for airborne pollutants from the ground source emissions in summer is stronger than that in winter. $\mathrm{OH}$ concentration in summer in mid-latitude is about 10 times its value in winter. High $\mathrm{OH}$ concentration speeds up the degradation of TNMHCs.

Mobile emission sources are predominantly characterized by high $\mathrm{NO}_{\mathrm{x}}$ and $\mathrm{CO}$ concentrations, and point emission sources by high $\mathrm{SO}_{2}$ and $\mathrm{NO}_{\mathrm{x}}$. So, the mobile sources have relatively low $\mathrm{SO}_{2} / \mathrm{NO}_{\mathrm{x}}$ ratios [40]. In the current study, the concentration ratios were $0.27,0.38,0.37,0.48$ and 0.39 for $\mathrm{SO}_{2} / \mathrm{NO}_{2}$ and $0.15,0.21,0.19$, 0.24 and 0.20 for $\mathrm{SO}_{2} / \mathrm{NO}_{x}$ during the winter, spring, summer, autumn and annual, respectively. These results indicate that the mobile emissions are the predominant source within the study area. The $\mathrm{SO}_{2} / \mathrm{NO}_{2}$ concentration 

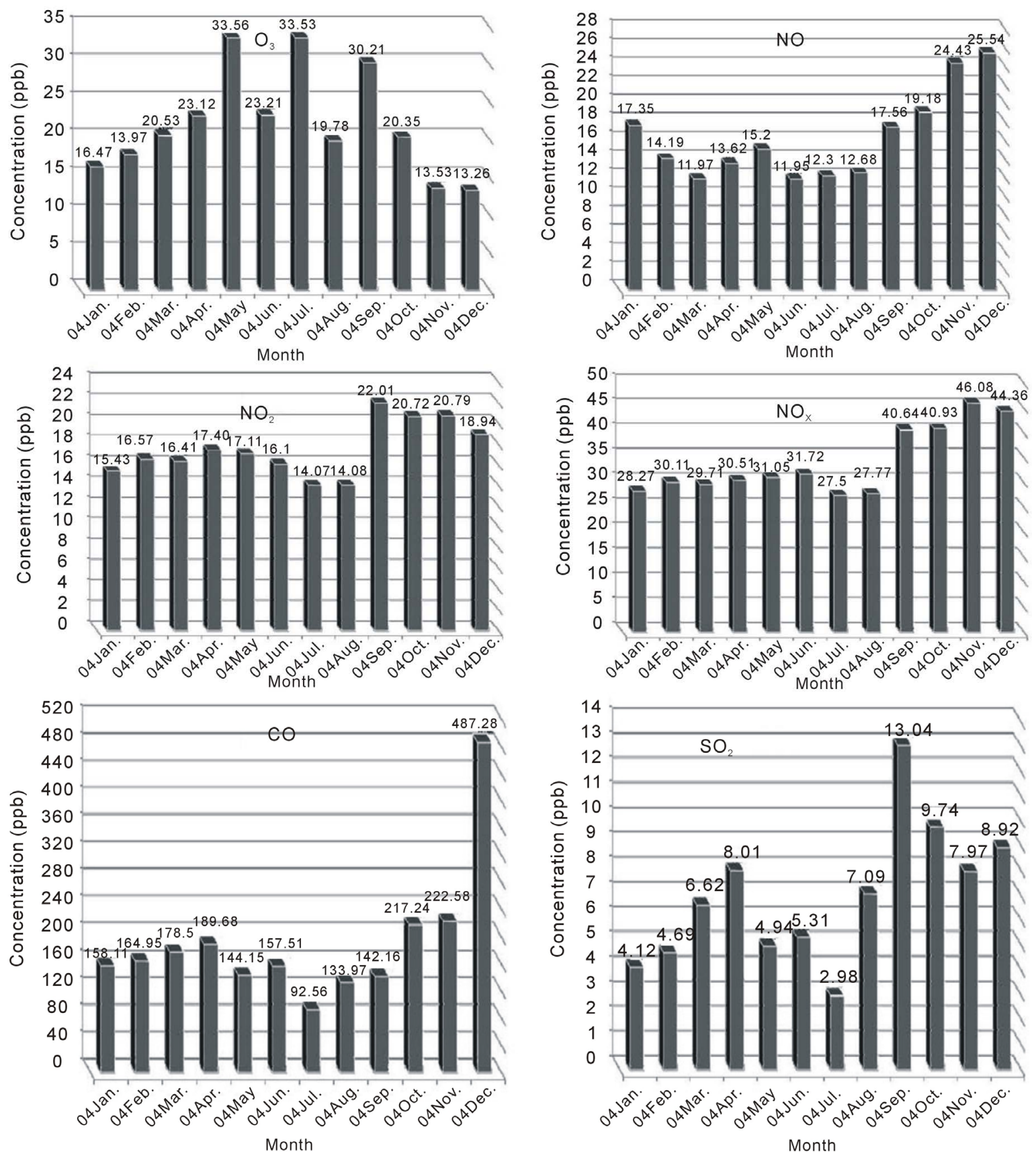

Figure 3. Monthly variation in concentrations of $\mathrm{O}_{3}, \mathrm{NO} . \mathrm{NO}_{2}, \mathrm{NO}_{\mathrm{X}}, \mathrm{CO}$ and $\mathrm{SO}_{2}$ in Yanbu during the period of study.

ratios at the study area during the period of study were similar to those found in Kolkata, India (ranged from $0.38-0.41),[41]$.

\subsection{Comparison of $\mathrm{O}_{3}$ and Its Precursors Levels in Yanbu Al Sinaiyah with Other International Cities}

The Saudi Arabia air quality standard for hourly $\mathrm{O}_{3}$ concentration is $150 \mathrm{ppb}$. Moreover, photochemical smog usually occurs when $\mathrm{O} 3$ concentration exceeds $100 \mathrm{ppb}$ [42]. The frequency percentage distribution of the hourly concentrations of $\mathrm{O}_{3}$ during the period of study is graphically presented in Figure 6. From this figure, it can be seen that the hourly $\mathrm{O}_{3}$ concentrations during the period of study not exceed the maximum $\mathrm{O}_{3}$ hourly set by 

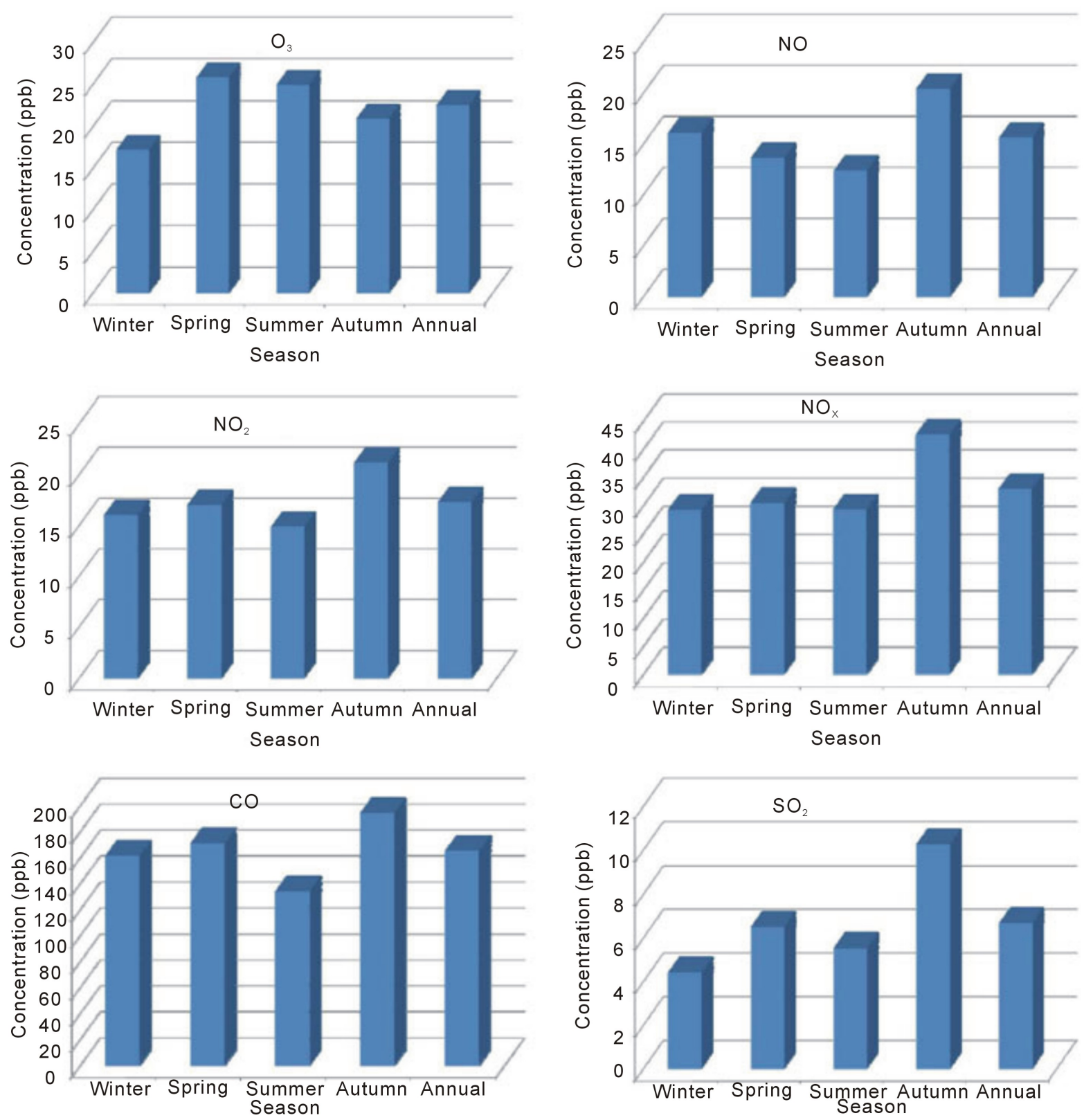

Figure 4. Seasonal variation in concentrations of $\mathrm{O}_{3}, \mathrm{NO} . \mathrm{NO}_{2}, \mathrm{NO}_{\mathrm{X}}, \mathrm{CO}$ and $\mathrm{SO}_{2}$ in $\mathrm{Yanbu}$ during the period of study.

Saudi Arabia air and the photochemical smog formation not occur during the period of study.

The annual average concentration of $\mathrm{O}_{3}$ and its precursors in Yanbu Al Sinaiyah were compared with these found in different locations in Saudi Arabia and over the world [8] [20] [30] [41] [43]-[54]. As shown in Table 2, the average concentrations of $\mathrm{NO}, \mathrm{NO}_{2}, \mathrm{NO}_{\mathrm{x}}, \mathrm{SO}_{2}, \mathrm{O}_{3}, \mathrm{CO}, \mathrm{CH}_{4}$ and NMHCs in the present study were lower/higher or similar to those detected in other cities of the world. For example, the $\mathrm{O}_{3}$ mean concentration in Yanbu Al Sinaiyah was similar to that found in Al-Taneem, KSA; Eskisehir, Turkey, and Nanjing, China, while it was higher than those found in Holy Makkah but it was lower than those found in Haram, Giza, Egypt. NO concentration was lower than those found in other locations except those found in Eskisehir, Turkey and Nanjing, China. $\mathrm{NO}_{2}$ concentration was lower when compared with those reported in other locations. $\mathrm{NO}_{\mathrm{x}}$ concentration was similar to that observed in Al-Taneem, Holy Makkah, KSA, while it was higher than that observed in Holy Makkah and it was lower than that recorded in Muna, $\mathrm{KSA}$. $\mathrm{SO}_{2}$ concentration was lower than those found in other locations. The $\mathrm{CO}$ concentration was lower when compared with those reported in other locations. $\mathrm{CH}_{4}$ 

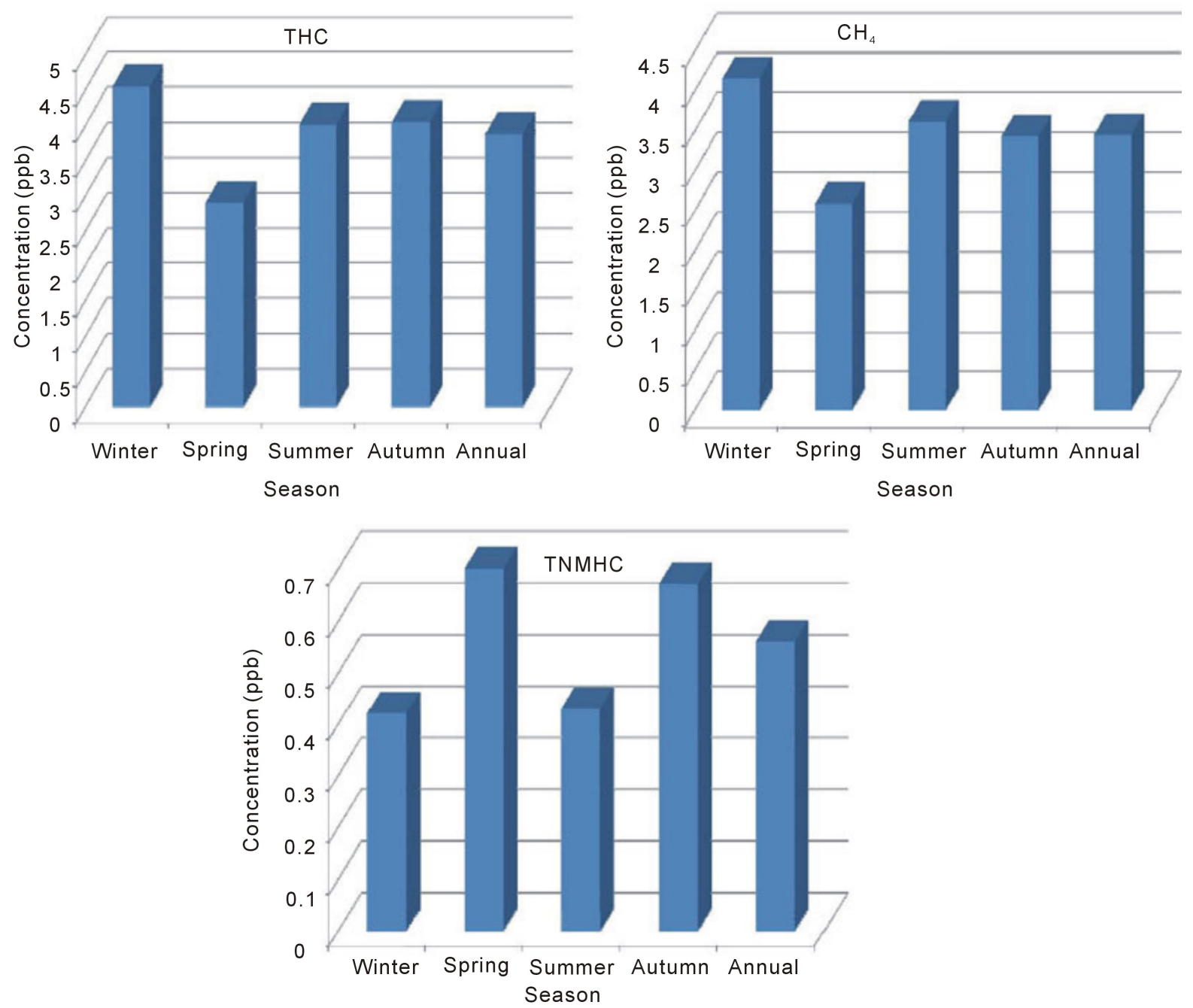

Figure 5. Seasonal variation in concentrations of $\mathrm{O}_{3}, \mathrm{THC}, \mathrm{CH}_{4}$ and TNMHC in Yanbu during the period of study.

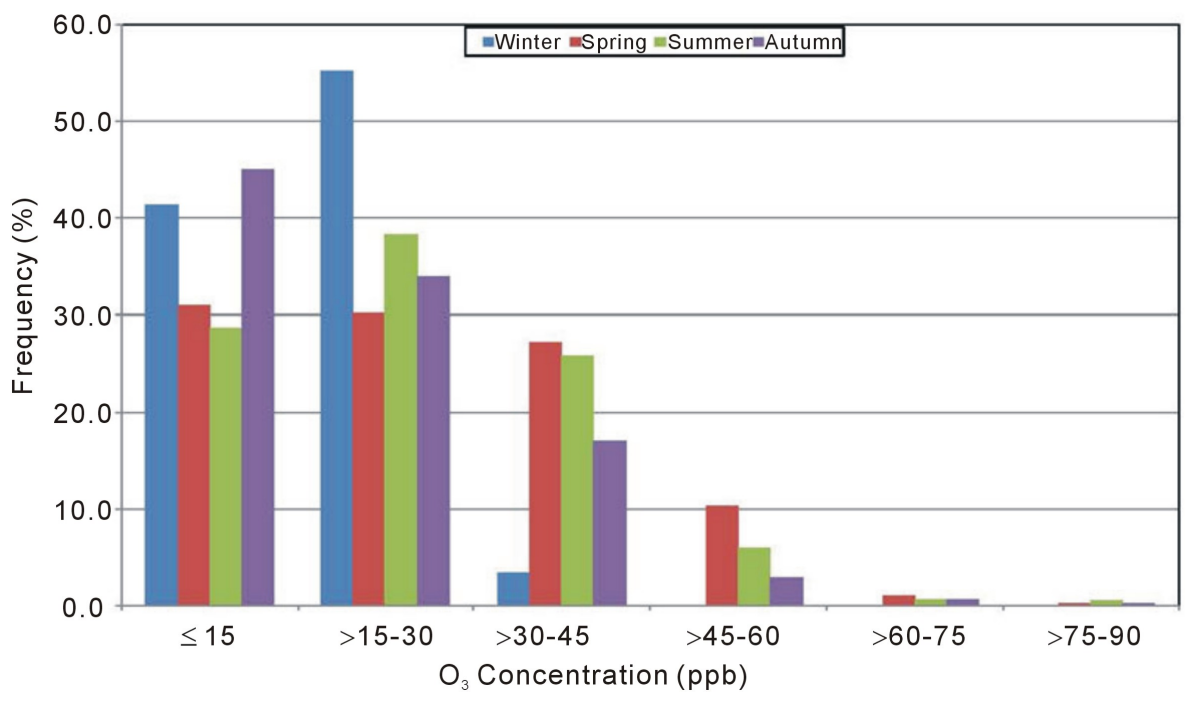

Figure 6. Frequency distribution of hourly ozone concentration during the different seasons. 
Table 2. Concentration of Ozone and its precursors at different sites all over the world.

\begin{tabular}{|c|c|c|c|c|c|c|c|c|c|}
\hline Site & $\begin{array}{c}\mathrm{O}_{3} \\
(\mathrm{ppb})\end{array}$ & $\begin{array}{l}\text { NO } \\
\text { (ppb) }\end{array}$ & $\begin{array}{l}\mathrm{NO}_{2} \\
\text { (ppb) }\end{array}$ & $\begin{array}{l}\mathrm{NO}_{\mathrm{x}} \\
(\mathrm{ppb})\end{array}$ & $\begin{array}{c}\mathrm{SO}_{2} \\
(\mathrm{ppb})\end{array}$ & $\begin{array}{c}\mathrm{CO} \\
\text { (ppb) }\end{array}$ & $\begin{array}{c}\mathrm{CH}_{4} \\
(\mathrm{ppm})\end{array}$ & $\begin{array}{l}\text { TNMHC } \\
\text { (ppm) }\end{array}$ & Reference \\
\hline Yanbu Al Sinaiyah, KSA & 22.5 & 15.6 & 17.3 & 32.8 & 6.7 & 165.1 & 3.44 & 0.56 & Present study \\
\hline Al-Taneem, KSA & 21.0 & 18.0 & - & 33.0 & 10.0 & 1386.0 & 2.15 & 0.39 & Al Jeelani (2009a) \\
\hline Holy Makkah, KSA & 4.0 & - & - & 15.0 & 16.0 & 11300.0 & - & - & Al Jeelani (2009b) \\
\hline Haram, Giza, Egypt & $40.0-79.0$ & - & $89.0-137.0$ & - & - & - & - & - & Khoder (2004) \\
\hline Haram, Giza, Egypt & $30.0-64.0$ & - & - & - & - & - & - & - & Khoder (2009) \\
\hline Dokki, Giza, Egypt & - & - & $70.0-98.0$ & - & $32.0-48.0$ & - & - & - & Khoder (2002) \\
\hline Eskisehir, Turkey & 19.0 & $8.0-16.0$ & - & - & - & - & - & - & özden et al. (2008) \\
\hline Ankara, Turkey & - & - & - & - & 11.0 & - & - & - & DRSCH (2006) \\
\hline Nanjing, China & 20.4 & 10.6 & 18.8 & - & - & 1130.0 & 1.89 & 0.13 & Jun et al. (2007) \\
\hline Beijing, China & - & 38.0 & - & - & 9.0 & 1970.0 & - & - & Wang et al. (2008) \\
\hline Germany & - & 18.0 & - & - & - & - & - & - & Lewne et al. (2004) \\
\hline Kolkata, India & - & 17.0 & - & - & - & - & - & - & Gupta et al. (2008) \\
\hline Dhaka, Bangladesh & - & - & - & - & 45.0 & - & - & - & Gurjar et al. (2008) \\
\hline Nagoya, Japan & - & - & - & - & - & - & - & 0.03 & Saito et al. (2009) \\
\hline London, UK & - & - & - & - & - & - & - & 0.03 & Derwent et al.(2000) \\
\hline Lille, France & - & - & - & - & - & - & - & 0.02 & Borbon et al. (2002) \\
\hline Seoul, Korea & - & - & - & - & - & - & - & 0.05 & Na and Kim (2001) \\
\hline
\end{tabular}

concentration was much higher than those found in other locations. The TNMHC concentration was higher than those recorded in other locations. Generally, the variation in the levels of atmospheric measured ozone and its precursors among the different locations of the world was presumably due to the difference in the traffic density, industrial activities, and intensity of human activities, land use patterns and the frequency of rainfall prior to sample collection.

\section{References}

[1] Godish, T. (2004) Air Quality. 4th Edition, CRC Press Inc., Boca Raton.

[2] Watson, A.Y., Bates, R.D. and Kennedy, D. (1988) Air Pollution, the Automobile, and Public Health. National Academy Press, Washington DC. http://dx.doi.org/10.1016/S1352-2310(99)00453-7

[3] Solomon, P., Cowling, E., Hidy, G. and Furiness, C. (2000) Comparison of Scientific Findings from Major Ozone Field Studies in North America and Europe. Atmospheric Environment, 34, 1885-1920.

[4] Lippmann, M. (2009) Environmental Toxicants: Human Exposures and Their HealthEffects. John Wiley \& Sons, Hoboken.

[5] Wilson, E.K. (2009) Ozone’s Health Impact. Chemical \& Engineering News, 87, 9. http://dx.doi.org/10.1021/cen-v087n011.p009a

[6] IPCC (2007) Climate Change 2007: The Physical Science Basis: Contribution of Working Group I to the Fourth Assessment Report of the Intergovernmental Panel on Climate Change. Cambridge University Press, Cambridge, New York.

[7] Sitch, S., Cox, P.M., Collins, W.J. and Huntingford, C. (2007) Indirect Radiative Forcing of Climate Change through Ozone Effects on the Land-Carbon Sink. Nature, 448, 791-794. http://dx.doi.org/10.1038/nature06059

[8] Jun, T., Xia, Z., Wang, H. and Li, W. (2007) Temporal Variations in Surface Ozone and Its Precursors and Meteorological Effects at an Urban Site in China. Atmospheric Research, 85, 310-337. http://dx.doi.org/10.1016/j.atmosres.2007.02.003

[9] Crutzen, P.J. (1974) Photochemical Reactions Initiated by and Influencing Ozone in Unpolluted Tropospheric Air. Tellus, 26, 47-56. http://dx.doi.org/10.1111/j.2153-3490.1974.tb01951.x

[10] Levy II, H., Mahlman, J.D., Moxim, W.J. and Liu, S.C. (1985) Tropospheric Ozone: The Role of Transport. Journal of Geophysical Research, 90, 3753-3772.

[11] Jallad, K.N. and Espada-Jallad, C. (2010) Analysis of Ambient Ozone and Precursor Monitoring Data in a Densely Populated Residential Area of Kuwait. Journal of Saudi Chemical Society, 14, 363-372. http://dx.doi.org/10.1016/j.jscs.2010.04.003 
[12] Fishman, J. and Crutzen, P.J. (1978) The Origin of Ozone in the Troposphere. Nature, 274, 855. http://dx.doi.org/10.1038/274855a0

[13] Beig, G., Gunthe, S. and Jadhav, D.B. (2007) Simultaneous Measurements of Ozoneand Its Precursors on a Diurnal Scale at a Semi Urban Site in India. Journal of Atmospheric Chemistry, 57, 239-253. http://dx.doi.org/10.1007/s10874-007-9068-8

[14] Abdul-Wahab, S.A. and Bouhamra, W.S. (2004) Diurnal Variations of Airpollution from Motor Vehicles in Residential Area. International Journal of Environmental Studies, 61, 73-98. http://dx.doi.org/10.1080/0020723032000130034

[15] Yang, C.-F. Ou, Lin, N.-H., Sheu, G.-R., Lee, C.-T. and Wang, J.-L. (2012) Seasonal and Diurnal Variations of Ozone at a High-Altitude Mountain Baseline Station in East Asia. Atmospheric Environment, 46, 279-288. http://dx.doi.org/10.1016/j.atmosenv.2011.09.060

[16] Elminir, H.K. (2005) Dependence of Urban Air Pollutants on Meteorology. Science of the Total Environment, 350, 225237. http://dx.doi.org/10.1016/j.scitotenv.2005.01.043

[17] Dueñas, C., Fernández, M.C., Cañete, S., Carretero, J. and Liger, E. (2002) Assessment of Ozone Variations and Meteorological Effects in an Urban Area in the Mediterranean Coast. Science of the Total Environment, 299, 97-113. http://dx.doi.org/10.1016/S0048-9697(02)00251-6

[18] Lehman, J., Swinton, K., Bortnick, S., Hamilton, C., Baldridge, E., Eder, B. and Cox, B. (2004) Spatio-Temporal Characterization of Tropospheric Ozone across the Eastern United States. Atmospheric Environment, 38, 4357-4369. http://dx.doi.org/10.1016/j.atmosenv.2004.03.069

[19] Satsangi, G.S., Lakhani, A., Kulshrestha, P.R. and Taneja, A. (2004) Seasonal and Diurnal Variation of Surface Ozone and a Preliminary Analysis of Exceedance of Its Critical Levels at a Semi-Arid Site in India. Journal of Atmospheric Chemistry, 47, 271-286. http://dx.doi.org/10.1023/B:JOCH.0000021156.04126.3b

[20] Saito, S., Nagao, I. and Kanzawa, H. (2009) Characteristics of Ambient $\mathrm{C}_{2}-\mathrm{C}_{11}$ Non-Methane Hydrocarbons in Metropolitan Nagoya, Japan. Atmospheric Environment, 43, 4384-4395. http://dx.doi.org/10.1016/j.atmosenv.2009.04.031

[21] Zhang, B.N. and Oanh, N.T.K. (2002) Photochemical Smog Pollution in the Bangkok Metropolitan Region of Thailand in Relation to $\mathrm{O}_{3}$ Precursor Concentrations and Meteorological Conditions. Atmospheric Environment, 36, 4211-4222. http://dx.doi.org/10.1016/S1352-2310(02)00348-5

[22] Sawyer, R.F., Harley, R.A., Cadle, S.H., Norbeck, J.M., Slott, R. and Bravo, H.A. (2000) Mobile Sources Critical Review: 1998 NARSTO Assessment. Atmospheric Environment, 34, 2161-2181. http://dx.doi.org/10.1016/S1352-2310(99)00463-X

[23] Placet, M., Mann, C.O., Gilbert, R.O. and Niefer, M. (2000) Emissions of Ozone Precursors from Stationary Sources: A Critical Review. Atmospheric Environment, 34, 2183-2204. http://dx.doi.org/10.1016/S1352-2310(99)00464-1

[24] Geron, C.D., Pierce, T.E. and Guenther, A.B. (1995) Reassessment of Biogenic Volatile Organic Compound Emissions in the Atlanta Area. Atmospheric Environment, 29, 1569-1578. http://dx.doi.org/10.1016/1352-2310(94)00274-O

[25] Crutzen, P.J., Heidt, L.E., Krasnec, J.P., Pollack, W.H. and Seiler, W. (1979) Biomass Burning as a Source of Atmospheric Gases CO, $\mathrm{H}_{2}, \mathrm{~N}_{2} \mathrm{O}$, NO, $\mathrm{CH}_{3} \mathrm{Cl}$, and COS. Nature, 282, 253-256. http://dx.doi.org/10.1038/282253a0

[26] Brewer, D.A., Olgiaruso, M.A., Aygustson, T.R. and Levine, J.S. (1984) The Oxidation of Isoprene in the Troposphere: Mechanism and Model Calculations. Atmospheric Environment, 18, 2723-2744. http://dx.doi.org/10.1016/0004-6981(84)90338-X

[27] Warneck, P. (1988) Chemistry of Natural Atmosphere. Academic Press, San Diego.

[28] Yang, K.L., Ting, C.C., Wang, J.L., Wingenter, O.W. and Chan, C.C. (2005) Diurnal and Seasonal Cycles of Ozone Precursors Observed from Continuous Measurement at an Urban Site in Taiwan. Atmospheric Environment, 39, 3221-3230. http://dx.doi.org/10.1016/j.atmosenv.2005.02.003

[29] Royal Commission for Jubail and Yanbu (2012) http://www.rcjy.gov.sa/ar-SA/Citizen/Yanbu/AboutCity/Pages/default.aspx\#

[30] Khoder, M.I. (2009) Diurnal, Seasonal and Weekdays-Weekends Variations of Ground Level Ozone Concentrations in an Urban Area in Greater Cairo. Environmental Monitoring and Assessment, 149, 349-362. http://dx.doi.org/10.1007/s10661-008-0208-7

[31] Lal, S., Naja, M. and Subbaraya, B.H. (2000) Seasonal Variations in Surface Ozone and Its Precursors over an Urban Site in India. Atmospheric Environment, 34, 2713-2724. http://dx.doi.org/10.1016/S1352-2310(99)00510-5

[32] Saito, S., Nagao, I. and Tanaka, H. (2002) Relationship of $\mathrm{NO}_{\mathrm{x}}$ and $\mathrm{NMHC}$ to Photochemical $\mathrm{O}_{3}$ Production in a Coastal and Metropolitan Areas of Japan. Atmospheric Environment, 36, 1277-1286. http://dx.doi.org/10.1016/S1352-2310(01)00557-X

[33] Murao, N., Ohta, S., Furuhashi, N. and Mizoguchi, I. (1990) The Causes of Elevated Concentration of Ozone in Sapporo. Atmospheric Environment. Part A. General Topics, 24, 1501-1507. http://dx.doi.org/10.1016/0960-1686(90)90059-V 
[34] Kelly, N.A. and Gunst, R.F. (1990) Response of Ozone to Changes in Hydrocarbon and Nitrogen Oxide Concentrations in Outdoor Smog Chambers Filled with Los Angeles Air. Atmospheric Environment. Part A. General Topics, 24, 29913005. http://dx.doi.org/10.1016/0960-1686(90)90479-7

[35] Latha, K.M. and Badarinath, K.V.S. (2003) Black Carbon Aerosols over Tropical Urban Environment-A Case Study. Atmospheric Research, 69, 125-133. http://dx.doi.org/10.1016/j.atmosres.2003.09.001

[36] Rao, T.V.R., Reddy, R.R., Sreenivasulu, R., Peeran, S.G., Murthy, K.N.V., Ahammed, Y.N., Gopal, K.R., Azeem, P.A., Sreedhar, B. and Sunitha, K. (2002) Air Space Pollutants CO and $\mathrm{NO}_{\mathrm{x}}$ Level at Anantapur (Semi-Arid Zone), Andhra Pradesh. Journal of Indian Geophysical Union, 3, 151-161.

[37] Rao, T.V.R., Reddy, R.R., Sreenivasulu, R., Peeran, S.G., Murthy, K.N.V., Ahammed, Y.N., Gopal, K.R., Azeem, P.A., Sreedhar, B. and Badarinath, K.V.S. (2002) Seasonal and Diurnal Variations in the Levels of $\mathrm{NO}_{\mathrm{x}}$ and CO Trace Gases at Anantapur in Andhra Pradesh. Journal of Indian Geophysical Union, 3, 163-168.

[38] Jo, W.K. and Park, J.H. (2005) Characteristics of Roadside Air Pollution in Korean Metropolitan City (Daegu) over Last 5 to 6 Years: Temporal Variations, Standard Exceedances, and Dependence on Meteorological Conditions. Chemosphere, 59, 1557-1573. http://dx.doi.org/10.1016/j.chemosphere.2004.12.021

[39] Qin, Y., Walk, T., Gary, R., Yao, X. and Elles, S. (2007) $\mathrm{C}_{2}-\mathrm{C}_{10}$ Nonmethane Hydrocarbons Measured in Dallas, USASeasonal Trends and Diurnal Characteristics. Atmospheric Environment, 41, 6018-6032. http://dx.doi.org/10.1016/j.atmosenv.2007.03.008

[40] Aneja, V.P., Roelle, P.A., Murray, G.C., Southerland, J., Erisman, J.W., Fowler, D., Asman, W.A.H. and Patni, N. (2001) Atmospheric Nitrogen Compounds II: Emissions, Transport, Transformation, Deposition and Assessment. Atmospheric Environment, 35, 1903-1911. http://dx.doi.org/10.1016/S1352-2310(00)00543-4

[41] Gupta, A.K., Karar, K., Ayoob, S. and Kuruvilla, J. (2008) Spatio-Temporal Characteristics of Gaseous and Particulate Pollutants in an Urban Region of Kolkata, India. Atmospheric Research, 87, 103-115. http://dx.doi.org/10.1016/j.atmosres.2007.07.008

[42] Guicherit, R., Jelters, R. and Lindquiate, F. (1972) Determination of Ozone Concentration in Outdoor Air near Delft, the Nether Land. Environmental Pollution, 3, 91-110. http://dx.doi.org/10.1016/0013-9327(72)90029-8

[43] Al-Jeelani, H.A. (2009) Air Quality Assessment at Al-Taneem Area in the Holly Makkah City, Saudi Arabia. Environmental Monitoring and Assessment, 156, 211-222. http://dx.doi.org/10.1007/s10661-008-0475-3

[44] Al-Jeelani, H.A. (2009) Evaluation of Air Quality in the Holly Makkah during Hajj Season 1425H. Journal of Applied Sciences Research, 5, 115-121.

[45] Khoder, M.I. (2004) Atmospheric Formation and Occurrence of Nitrous Acid and Its Role in the Formation of Ozone in the City Centre in Cairo, Egypt. Egyptian Journal of Chemistry, 47, 189-209.

[46] Khoder, M.I. (2002) Atmospheric Conversion of Sulfur Dioxide to Particulate Sulfate and Nitrogen Dioxide to Particulate Nitrate and Gaseous Nitric Acid in an Urban Area. Chemosphere, 49, 675-684 http://dx.doi.org/10.1016/S0045-6535(02)00391-0

[47] Özden, Ö., Döğeroğlu, T. and Kara, S. (2008) Assessment of Ambient Air Quality in Eskişehir, Turkey. Environment International, 34, 678-687. http://dx.doi.org/10.1016/j.envint.2007.12.016

[48] DRSCH (Directory of RefikSaydam Center of Hygiene) (2006) Research Directorate of Environmental Health. www.rshm.saglik.gov.tr.

[49] Wang, W.X., Chai, F.H., Zhang, K., Wang, S.L., Chen, Y.Z., Wang, X.Z. and Yang, Y.Q. (2008) Study on Ambient Air Quality in Beijing for the Summer 2008 Olympic Games. Air Quality, Atmosphere \& Health, 1, 31-36. http://dx.doi.org/10.1007/s11869-008-0003-1

[50] Lewne, M., Cyrys, J., Meliefste, K., Hoek, G., Brauer, M., Fischer, P., Gehring, U., Heinrich, J., Brunekreef, B. and Bellander, T. (2004) Spatial Variation in Nitrogen Dioxide in Three European Areas. Science of the Total Environment, 332, 217-230. http://dx.doi.org/10.1016/j.scitotenv.2004.04.014

[51] Gurjar, B.R., Butler, T.M., Lawrence, M.G. and Lelieveld, J. (2008) Evaluation of Emissions and Air Quality in Megacities. Atmospheric Environment, 42, 1593-1606. http://dx.doi.org/10.1016/j.atmosenv.2007.10.048

[52] Derwent, R.G., Davis, T.J., Delaney, M., Dollard, G.J., Field, R.A., Dumitrean, P., Nason, P.D., Jones, B.M.R. and Pepler, S.A. (2000) Analysis and Interpretation of the Continuous Hourly Monitoring Data for $26 \mathrm{C}_{2}-\mathrm{C}_{8}$ Hydrocarbons at 12 United Kingdom Sites during 1996. Atmospheric Environment, 34, 297-312. http://dx.doi.org/10.1016/S1352-2310(99)00203-4

[53] Borbon, A., Locoge, N., Vellerot, M., Galloo, J.C. and Guillermo, R. (2002) Characterization of NMHCs in a French Urban Atmosphere: Overview of the Main Sources. Science of the Total Environment, 292, 177-191. http://dx.doi.org/10.1016/S0048-9697(01)01106-8

[54] Na, K. and Kim, Y.P. (2001) Seasonal Characteristics of Ambient Volatile Organic Compounds in Seoul, Korea. Atmospheric Environment, 35, 2603-2614. http://dx.doi.org/10.1016/S1352-2310(00)00464-7 